Nóra I. Jakab, Ph.D., Associate Professor

University of Miskolc

Faculty of Law

civnora@uni-miskolc.hu

Zsófia P. Ráczi, Student of Labour and Social Security Administration, University of Miskolc

Faculty of Law

zsofiaraczi@gmail.com

\title{
ISSUES OF PUBLIC SOCIAL RESPONSIBILITY IN GREAT BRITAIN AND HUNGARY*
}

\begin{abstract}
Social responsibility has undergone significant development in recent years. The concept has been a success for every aspect of life, personal life, the economic sphere, and finally the public sector. At present, many states are struggling with proven problems in the public sector, and public social responsibility is one of the guidelines under which a comprehensive public administration reform could be launched. In this study we examine the British and Hungarian solutions of social public responsibility. The United Kingdom's example, though ahead of us, is not sure that the fundamental legal and mindset differences make the other European countries the same way to implement the PSR that works in the Anglo-Saxon kingdom.
\end{abstract}

Keywords: social responsibility - social public responsibility - public service social value law, innovative service provision.

\section{INTRODUCTION}

Nowadays humanity has to face a number of overpowering global challenges. There are both economic, social and environmental problems, and these are often

* „The described article/presentation/study was carried out as part of the EFOP-3.6.1-162016-00011 "Younger and Renewing University - Innovative Knowledge City - institutional development of the University of Miskolc aiming at intelligent specialisation" project implemented in the framework of the Szechenyi 2020 program. The realization of this project is supported by the European Union, co-financed by the European Social Fund." 
linked to, catalyzed and enhanced by each other. According to the more optimistic research, the next 50 years will determine the next 10,000 years. However, less optimistic researchers only give humanity 10-15 years to save itself before climate change and other processes related to environmental and social challenges become irreversible.

In 2018 the most threatening global catastrophic risks included the weapons of mass destruction (nuclear warfare, biological and chemical warfare), climate change, ecological collapse, pandemics and artificial intelligence. ${ }^{1}$ Overpopulation, poverty and the exploitation of the poor, the ever-increasing plastic-pollution or even discrimination are challenges with which humanity has been struggleing for many years now. How do we cope with these problems? Whose responsibility it is to save the planet and the people? What should we do? Is there any hope? These issues have never been so topical, so urgent and so vital as they are today.

The concept of social responsibility aims to mitigate and remedy the aforementioned and other economic, social and environmental problems. Behind the responsibility for each other, the environment and society there are values and emotions that can make our world a better place, such as solidarity, morality and selflessness.

Social responsibility first appeared in the economic sector. Most of the literature agrees that the concept of Corporate Social Responsibility ${ }^{2}$ (CSR) first emerged in the 1950s, and it is linked to the American Howard R. Bowen's work, titled Social Responsibilities of the Businessman. In his work, Bowen concluded that large companies are the centers of power, and that their activities have a significant impact on citizens' lives, and asked "what responsibilities to society can business people be reasonably expected to assume?"3

Then CSR has been developing slowly until the mid-1980s, when the UN noticed that increasing environmental and social burdens are threatening the planet and humanity with rising danger. In 1983, in response to this threat, the UN set up the World Commission on Environment and Development (better known as the Brundtland Commission). ${ }^{4}$ During its operation between 1984 and 1987,

${ }^{1}$ Global Catastrophic Risks 2018. Annual Report - Global Challenges Foundation https:// api.globalchallenges.org/static/files/GCF-Annual-report-2018.pdf(14 March 2019)

${ }^{2}$ See more: Szegedi Krisztina, Mélypataki Gábor, „A vállalati társadalmi felelősségvállalás (CSR) és a jog kapcsolata" Miskolci jogi Szemle, 1/2016, 51-70. Kun Attila, A multinacionális vállalatok szociális felelössége, Ad Librum Kft., Budapest, 2009. Kun Attila, „Kötelezettség vagy önkéntesség? A társadalmi felelősség kérdése és a jogi megfelelés kultúrája”, Jánosik O., Vörös A. (ed.): Társadalmi felelösségvállalás. Mit tehet a közszféra? HOPPÁ Disszeminációs füzetek, 2012,36., http://issuu.com/budapestimuvkp/docs/gsr_kiadvany_honlapra/13? e=1618624/14469561, (25 September 2018)

${ }^{3}$ Howard R. Bowen, Social responsibilities of the businessman, Harper \& Row, New York, 1953, 16-50.

${ }^{4}$ Named after the Norwegian Prime Minister, Gro Harlem Brundtland, who was the head of the commission 
the Commission tried to find solutions to global environmental and social problems. The results of their work were published in a report. As a solution to the problems, the Commission considered sustainable development as the right tool. They defined it as a development that meets the needs of the present without compromising the ability of future generations to meet their own needs. ${ }^{5}$

Three areas (natural-environmental, economic, and social) have been studied by the Commission in a complex way - these areas are commonly referred to as the three pillars of sustainable development. ${ }^{6}$ The results of the report gradually reached the corporations, and began to shape and reform their approach.

In the 1990s and 2000s, social and environmental problems worsened at an accelerated pace, despite all previous efforts. In these decades CSR has become a global phenomenon, but there are also territorial specificities in different states, regions and continents. Several international organizations and the European Union have also focused on this issue. On the other hand, not only CSR has developed in the recent period, but social responsility itself has begun to spread to other areas.

For example, one of these new areas, trends of social responsibility is personal/individual social responsibility, which can be defined „as the way a person performs in his daily life as a member of the society - and not only as a consumer - basing his decisions in a desire to minimize the negative impacts and maximize the positive impacts on the social, environmental and economic environment in the long run. This range of personal behavior, more than as a consumer role, directly and indirectly embodies the economic, legal, ethical, discretionary and environmental actions derived from the individual's role in the marketplace, the society, the environment and the world as a whole." It is also one of the newest trends to study that what social value digital transformation does stands for. The GSR trend, in which corporate (CSR), public, civil and personal social responsibility are connected and globalized in order to solve problems concerning the whole society and to exploit different opportunities through cooperation, is also getting stronger. ${ }^{8}$

I would like to highlight and present in detail one of these new forms of social responsibility, namely Public Social Responsibility (PSR), which concept covers the social responsibility of the public sector.

\footnotetext{
${ }^{5}$ Report of the World Commission on Environment and Development: Our Common Future http://www.un-documents.net/our-common-future.pdf(14 March 2019)

${ }^{6}$ Report of the World Commission on Environment and Development: Our Common Future http://www.un-documents.net/our-common-future.pdf(14 March 2019)

${ }^{7}$ S. López Davis, L. Marín Rives, S. Ruiz De Maya, „Introducing Personal Social Responsibility as a key element to upgrade CSR", Spanish Journal of Marketing - ESIC, 2/2017, 146-163

${ }^{8}$ In virtue of what has been said at: Társadalmi érték és felelősség a közszférában (Social Value and Responsibility in the Public Sector) conference, National University Of Public Service (Nemzeti Közszolgálati Egyetem), Budapest, 11 September 2018.
} 


\section{PUBLIC SOCIAL RESPONSIBILITY}

The organizations of the public sector around the world all carry out activities that can be categorized as taking social responsibility, because they perform their activities in the public interest. However, the recognition that activities carried out in the public interest are not automatically socially responsible activities is spreading. It is not easy to understand this observation, as public responsibility is a self-evident consequence of the serving of the public weal, but it does not include social responsibility. That is why it is necessary to interpret public social responsibility and to visualize it as a public administrative function. ${ }^{9}$

PSR is therefore linked to the specific field of activity of public sector institutions. The monitoring of these institutions and public responsibility is partly realised through publicity. This responsiblity will become public social responsibility if the organization, beyond its statutory tasks, carries out activities that contribute to meeting important social needs or solving problems. ${ }^{10}$

Fundamentally public responsibility arises from the obligation of law. However, public sector organizations have some room for maneuver to serve the public interest and the public weal beyond the mandatory tasks.

There are already terms and references in previous documents that have shown that social responsibility will soon be deliberately spreading from business to other areas, especially to public administration. For example, ISO 26000 defines organizations as the category of those who can take social responsibility. According to the standard, there is a growing demand from society for organizations that are socially responsible. ${ }^{11}$ The information material prepared for this document goes even further, since it specifys its purpose as to constitute a stepping stone for organizations in both the public and private sectors to implement ISO 26000.12

Social responsibility in the public sector has been gaining attention in recent years. This is evidenced by the fact that many research and projects focus on this area, including, for example a project named Governmental Social Responsibility Model: An Innovative Approach of Quality in Governmental Operations and Outcomes, which was carried out within the confines of the South East Europe Transnational Cooperation Programme, funded by the European Union.

\footnotetext{
${ }^{9}$ In virtue of what has been said at: Társadalmi érték és felelősség a közszférában (Social Value and Responsibility in the Public Sector) conference, National University Of Public Service (Nemzeti Közszolgálati Egyetem), Budapest, 11 September 2018.

${ }^{10}$ The Public Social Responsibility (PSR) strategy of GVH (Hungarian Competition Authority) http://www.gvh.hu/data/cms1036194/GVH_PSR_strategia_2017_04_27.pdf(14 March 2019)

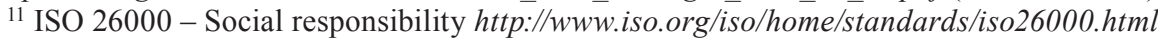
(14 March 2019)

${ }^{12}$ Discovering ISO 26000 https://www.iso.org/files/live/sites/isoorg/files/archive/pdf/en/ discovering_iso_26000.pdf(12 February 2019)
} 
The project started with the participation of 6 states: Greece, Italy, Bulgaria, Romania, Hungary and Bosnia and Herzegovina. The project was based on the fact that increasing CSR activity has stirred up the lives of companies and has brought many benefits to them, such as increased customer satisfaction and positive changes in organizational culture. The initiators of the project realized that strengthening social responsibility in the public sector would be feasible. Public institutions in the participating countries face a number of challenges, such as the increasing demand for quality services, improving customer relationships, or increasing trust in institutions. All of these are not only the consequence of the scale of institutional capacities, but rather the attendants of organizational culture.

In the solution of these tasks, according to the concept of the project, it can be of great help to take over the CSR experience accumulated in the field of social responsibility, and to translate the established practices into the public sector. Such changes, principles and procedures can be successful in overcoming challenges as commitment to continuous improvement of quality, effective collaboration with the stakeholders of public institutions, adaptation of conscious and socially responsible philosophys, and moderate use of the natural environment. To sum up, the project is intended to help the public sector to translate the concepts of social responsibility and quality.

Significant results were expected from the program, such as the development of a mechanism to provide effective, innovative tools for progress, transfer of the best practices, contribution to public service policies, and the rectifying of operational and regulatory frameworks to increase social responsibility, organizational development and higher quality services. ${ }^{13}$

\section{THE PSR EXAMPLE OF THE UNITED KINGDOM}

The UK Government has been doing a pioneer work in the field of social responsibility for many years now. There are several documents that prove that the British government considers it compulsory to set an example when it comes to social responsibility.

One of these evidences is the Greening Government Commitments Annual Report, published by the Department for Environment, Food and Rural Affairs in the February of 2018. It is formulated in the foreword that the Government's ambition is to lead by example in the respect of commitments. The report lists the

${ }^{13}$ Governmental Social Responsibility Model: An Innovative Approach of Quality in Governmental Operations and Outcomes https://www.mh.government.bg/medialfiler_public/2015/04/30/broshura.pdf(25 March 2019) 
measures and results that have been implemented and achieved by the 22 ministries and other government agencies through over 80 pages. $^{14}$

Earlier CSR reports from the UK government also point out how important it is to the leadership to set an example on social responsibility and to create the right framework and motivation for companies to develop and continue their CSR practices. $^{15}$

In 2012, the British leadership adopted the Public Service Social Value Act ${ }^{16}$, which came into force on the 31th of January in 2013. This Act requires public authorities to have regard to economic, social and environmental well-being in connection with public services contracts, purchases, investments, support programs and other activities. In order to comply with the Act, before they start the procurement process, authorities must think about how what they are going to buy, or how they are going to buy it, could add extra social value. The Social Value Act can be described as a tool for the wider dissemination of creating social value and for gaining more value with the same investment and money. ${ }^{17}$ It also encourages commissioners to talk to their local provider market or community to design better services, often finding new and innovative solutions to difficult problems. ${ }^{18}$

But what social value is? According to the definition made by The Sustainable Procurement Task Force, social value is the result of a process whereby organisations meet their needs for goods, services, works and utilities in a way that achieves value for money on a whole life basis in terms of generating benefits not only to the organisation, but also to society and the economy, whilst minimising damage to the environment. ${ }^{19}$

Social value creation is a strategy that targets social, economic and sustainability / environmental issues. Social value, or benefit is created when a sustain-

${ }^{14}$ Greening Government Commitments Annual Report April 2016 to March 2017, February 2018. https://assets.publishing.service.gov.uk/government/uploads/system/uploads/attachment data/file/679636/ggc-annual-report-2016-17.pdf(14 January 2019)

${ }^{15}$ Corporate Responsibility Report - HM Government, 2008 https://www.educationandemployers.org/wp-content/uploads/2014/06/corporate-responsibility-report-hm-gov.pdf (14 January 2019)

${ }^{16}$ Public Services (Social Value) Act, 2012. https://www.legislation.gov.uk/ukpga/2012/3/ contents/enacted (14 January 2019)

${ }^{17}$ Social Value Act Review, Cabinet Office, 2015. February https://assets.publishing.service. gov.uk/government/uploads/system/uploads/attachment_data/file/403748/Social_Value_Act_review_report_150212.pdf(14 January 2019)

${ }^{18}$ Guidance: Social Value Act: Information and Resources, Cabinet Ofiice, 2016. May https:// www.gov.uk/government/publications/social-value-act-information-and-resources/social-value-act-information-and-resources (14 January 2019)

${ }^{19}$ The Sustainable Procurement Task Force - Procuring The Future https://assets.publishing. service.gov.uk/government/uploads/system/uploads/attachment_data/file/69417/pb11710-procuring-the-future-060607.pdf (14.01.2019) 
ability strategy is applied well, thus when - as shown in the following figure people's interests, economic interests and environmental awareness, sustainability are realized at the same time..$^{20}$

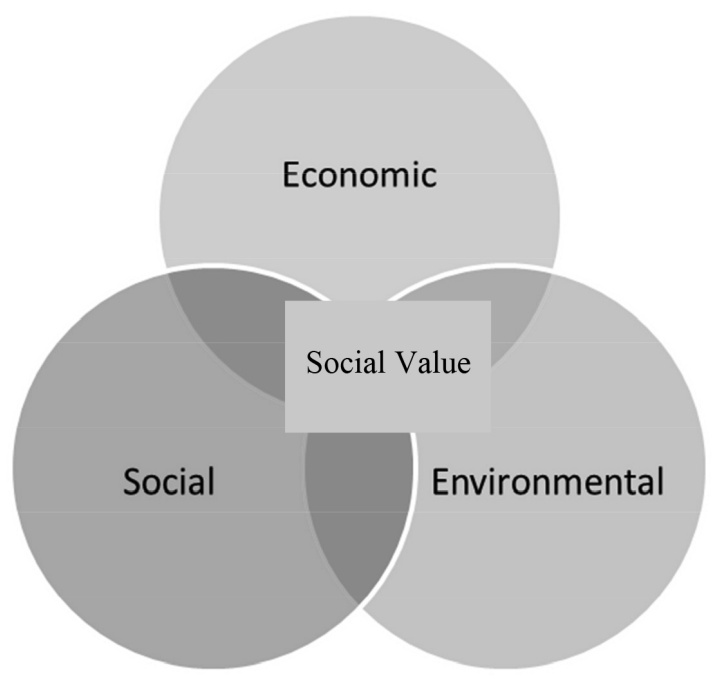

Social Value, Source: Own edit

If we are to summarize the purpose of the Public Service (Social Value) Act, we have to establish that the aims of the Act are twofold. On the one hand, the regulation aims to support VCSEs ${ }^{21}$ and local $\mathrm{SMEs}^{22}$ gain more access to public contracts. On the other hand, it is also the purpose of the Act to change previously established practices by shifting the focus from price onto wider social, economic and environmental factors when selecting a contractor. ${ }^{23}$

But how can this be put into practice? When it is applied well in the designing of the services, the Act can bring much more holistic and innovative results, than the previous practices. Service design with social value in mind can not only be a cost-saving tool, but it can deliver additional benefits to the community through the way that a service is run, too. There are several elements that can be added to the design of the service, and have such long-term and constant benefits. For example, employing a diverse workforce, or improving their skills and access

${ }^{20}$ In virtue of what has been said at: Társadalmi érték és felelősség a közszférában (Social Value and Responsibility in the Public Sector) conference, National University Of Public Service (Nemzeti Közszolgálati Egyetem), Budapest, 11 September 2018.

${ }^{21}$ Voluntary, Community and Social Enterprises

22 Small and Medium-sized Enterprises

${ }^{23}$ Sarr-William Jabang, An investigation into the use of public procurement and commissioning to deliver community (societal) value, $\mathrm{PhD}$ thesis, 2016, 15-18 
to digital technology brings social advantages. Creating opportunities for Small and Medium Enterprises, or employing from a local community or disadvantaged groups involves long-term economic benefits. The continuous emergence of environmental interest for instance can be achieved by monitoring greenhouse gas emissions, water consumption management or carbon reduction or offsetting. ${ }^{24}$

In the United Kingdom most of the local authorities have developed their own use, their own practice in terms of social value. However, there are some general policies that are followed by all authorities. For example, the Social Value Act is applied to any contracts that exceeds the 50000 Euro limit. When suppliers and contractors submit their applications, they should place particular emphasis on the social value that can be created.

For the sake of comparability and to make judgement easier, social value can be expressed in money. The National Social Value Measurement Framework provides a unified measurement and reporting standard for organizations. ${ }^{25}$

Generally suppliers or contractors who are able to provide the service at the least cost while meeting the social, economic and/or environmental needs of the local community would most likely win the bid for public service contracts. ${ }^{26}$

Here is a simple example to understand social value: imagine that a local government or a public institution has to hire a new employee. It advertises the position, and in the end there are two applicants to choose from. The job does not require any special qualifications. The first applicant has good family background, clean criminal record and has received appropriate education. It is sure that he could easily find another job. The second applicant does not have clean criminal record and comes from unsettled living conditions. If the municipality performs the measurement of added social value, it will come to the conclusion that it should choose the second applicant, because his/her employment creates much more social value. By providing a job for him/her, there is a good chance that he/she will avoid recidivism. What's more he/she isn't likely to easily get another job, while the other applicant is. ${ }^{27}$

${ }^{24}$ The Public Service (Social Value) Act 2012: An introductory guide for commissioners and policymakers; Department for Digital, Culture, Media \& Sport, 2018. https://assets.publishing. service.gov.uk/government/uploads/system/uploads/attachment_data/file/690780/Commissioner Guidance_V3.8.pdf(20 October 2018)

${ }^{25}$ In virtue of what has been said at: Társadalmi érték és felelősség a közszférában (Social Value and Responsibility in the Public Sector) conference, National University Of Public Service (Nemzeti Közszolgálati Egyetem), Budapest, 11 September 2018.

${ }^{26}$ Rana Khazbak: Social Value in Procurement, NLGN, WSP Birmingham, 2016. https:// www.base-uk.org/sites/default/files/news/Social-Value-in-Procurement_EVENT-WRITEUP.pdf (20 October 2018)

${ }^{27}$ In virtue of what has been said at: Társadalmi érték és felelősség a közszférában (Social Value and Responsibility in the Public Sector) conference, National University Of Public Service (Nemzeti Közszolgálati Egyetem), Budapest, 11 September 2018. 
Municipalities have reported a number of benefits brought to them by the measurement and application of social value. For example they could maximise the created value, gain competitive advantage and enhance both internal and external communications. ${ }^{28}$

There can be many positive effects of applying social value. These possible outcomes can be divided into three categories: jobs and economic growth; health, well-being and environment; and finally, the group of the impacts on the community. In the first area, there may be such positive consequences as thriving local businesses or long-term employment for local people with the right skills. Possible outcomes like easily accessible and sustainable transportation, healthy local air quality, or the limited use of resources and the cutting down on the creation of waste can be classified into the category of health, well-being and environment. The final group includes outcomes that strengthen the local community, such as the use of buildings and land for diverse purposes, or increasing community awareness. ${ }^{29}$

However, there are also some critics about the Public Services (Social Value) Act. In 2015, two years after the act came into force, its first review took place by the govenrment. They had to take stock of how the act triggered its expectations, what impact it had, and had to find out all the circumstances that might hinder its implementation. As a result of the review, they found that, where the Act is being used, it has an undoubtedly positive impact and that the variety of organisations that support the Act is quite striking. They also identified three major barriers that can prevent the implementation, and set up remedies for them. The first obstacle the review found was that awareness and take-up of the Act was a mixed picture. For example, many commissioners are aware of the Act and report that they consider social value, but far fewer have a fully developed strategy or policy in place. To overcome this problem, the review recommended the government to put more emphasis on awareness-raising. The second barrier was due to the not unitary method of implementation, which led to inconsistent practices. The differences in implementation were the most evident in the definition and application of social value. In this case, the document recommended the Cabinet Office to promote better understanding of how to practically apply the Act, particularly around knowing how to define social value and how and when to include it during the procurement process, applying social value within a legal framework and procurement rules, clarifying its use in preprocurement. The third limiting factor they found was the undeveloped social value measurement system. A voluntary

${ }^{28}$ Benefits of Social Value http://www.socialvalueuk.org/what-is-social-value/the-benefitsof-social-valuel (15 January 2019)

${ }^{29}$ Social Value in New Development: An Introductory Guide for Local Authorities and Development Teams, UK Green Building Council, March, 2018. https://www.ukgbc.org/wp-content/ uploads/2018/03/Social-Value.pdf (20 October 2018) 
initiative, the Inspiring Impact, was found to be the suitable tool for solving this problem. In essence, Inspiring Impact is a 10 -year program designed to develop units of measurement of various effects, and that's why they have been asked to help develop a customized system for measuring social value. ${ }^{30}$

The government was not the only one to make critical statements about the Act. The Social Value Act is widely acknowledged as a step in the right direction, and although its intentions are commendable, it has been widely criticised for its weaknesses. According to critical voices, it is not robust enough, and to ask commissioners to 'consider' social benefits does not go far enough. What's more there is no obligation for commissioners or procurement professionals to monitor their actions in this respect. Many also find it a weakness that dedicated training and awareness raising to increase knowledge of social value, or indeed the Social Enterprise Sector has not been built into the Act. ${ }^{31}$

To summarize the example of Great Britain I would like to highlight some major points of the practice of social value. The Social Value Act is considered as a powerful tool for local governments and other public service organisations to consider the broader definition of longer term value for money. As local authorities are looking at ways to redesign services in a way to meet cost saving pressures, they can use the Act as a tool to achieve that while at the same time deliver better and more innovative services. Done well, considering social value can have a positive impact on demand management, and reduce pressures on councils in the future. ${ }^{32}$

\section{PSR IN HUNGARY}

In Hungary, the practice of public social responsibility has been present in latent ways so far. For example, the first CSR Action Plan (2015.), and many of our acts, norms, already contain some PSR elements, and also prescribe the state to lead by example.

Within the confines of the Governmental Social Responsibility Model: An Innovative Approach of Quality in Governmental Operations and Outcomes project research has been carried out in Hungary as well. A focus group has been created from public sector employees, with about 40 participants, and they have

\footnotetext{
${ }^{30}$ Social Value Act Review, Cabinet Office, February 2015 https://assets.publishing.service. gov.uk/government/uploads/system/uploads/attachment_data/file/403748/Social_Value_Act_review _report_150212.pdf(20 October 2018)

${ }^{31}$ A Social Value Act for Northern Ireland - Social Enterprise NI Position Paper, 2017, https://www.socialenterpriseni.org/sites/default/files/tenders/Social\%20Value\%20Act\%20Position \%20Paper\%20310117.pdf (20 October 2018)

${ }^{32}$ Rana Khazbak: Social Value in Procurement, NLGN, WSP Birmingham, 2016. https:// www.base-uk.org/sites/default/files/news/Social-Value-in-Procurement_EVENT-WRITEUP.pdf (20 October 2018)
} 
been asked questions about the introduction of PSR practices in Hungary, the role and opportunities of the state in social responsibility, and it has been examined that in the key areas (organizational management, labour, correct and transparent operation, environment, customer relationship, human rights and community development), what possible actions can be taken. The discussions with the focus group indicates that the public sector is open to and even interested in the idea of PSR. The employees's ideas, suggestions and the practices already implemented have shown that the public sector is strongly inclined to review and rethink its activities in the aspect of social responsibility. ${ }^{33}$

Several organizations and two municipalities ${ }^{34}$ have already made their own PSR strategy. The Hungarian Competition Authority is the pioneer of public social responsibility in the country, which established its own PSR strategy before any other organization in 2016. For the time being, among the higher education institutions, the Neumann János University in Kecskemét has committed itself to developing its own strategy, and for example the National Media and Infocommunication Authority and The Hungarian Chamber of Agriculture also possess some aims in connection social responsibility.

The Hungarian Competition Authority in its PSR strategy declares that its strategy is also intended to serve as a model for other public institutions, both in Hungary and internationally, as it is not a practice in the public sector to have a social responsibility strategy, not even in the most developed countries.

As a conclusion, we would say that Hungary is ready for public social responsibility. The real question is whether we need the central, statutory regulation of the area in a manner similar to the British example, or is it enough to let the practice to develop at its own pace.

We consider it important to emphasize that many of the Hungarian public organizations that have already successfully formulated and applied a social responsibility strategy had received help to develop it. However, establishing a PSR strategy does not only or not even need financial assistance. The biggest obstacle to the preparation of PSR documents is the lack of expertise, and in our opinion this is the area where organizations should be provided with assistance. ${ }^{35}$

${ }^{33}$ Social responsibility - What can the public sector do? HOPPÁ Dissemination Papers, Tempus Public Foundation 36/2012.

${ }^{34}$ Alsómocsolád in 2016. and Budaörs in 2017.

35 The situation is similar for example in Romania. Romanian organizations became familiar with the modern concept of CSR during the 1990s. During the 2000s, the negotiations and preparative measures for accession to the EU changed Romanian organizations and enterprises toward CSR. However, according to various surveys the meaning of CSR remains blurry to most of the Romanian companies, and CSR in Romania is still at an early stage of development. Considering the reltionship between social responsibility and the Romanian government, it can be stated The Romanian government is not particularly engaged in promoting social responsibility, and legislation is mainly limited to the area of CSR. The statutory framework of CSR is largely in 
We believe that the other factor why the practice of PSR is not more widespread, is that the concept is not yet infiltrated into public awareness. Given that it is a recent, emerging practice, it is perfectly understandable, but WE are sure that public social responsibility is a trend that is expected to gather significant ground in the upcoming years.

\section{Closing remarks}

Social responsibility has undergone significant development in recent years. The concept has spread into every aspect of life: personal life, the economic sphere and finally the public sector.

Despite the fact that the PSR is still in its infancy in most countries, it is imperative to consider it when it comes to the future of the public sector or social responsibility. It is proven that currently many states are struggling with various problems in the public sector. I believe that public social responsibility is one of the guidelines with which help, for example, a comprehensive public administration reform could be launched. It is no coincidence that nowadays several researches are dealing with the issue.

The example of the United Kingdom is ahead of us, but it is not certain that the fundamental legal and mindset differences will give the other European countries the same way to implement the PSR that works in the Anglo-Saxon kingdom.

However, we would like to draw attention to the fact that we should not forget about the original motives behind the concept of social responsibility, the hidden behind it, solidarity, morality, empathy and similar important values. We cannot forget these because different social responsibility practices are only workable and feasible if there is a real need on the part of society and if the community feels the values in question.

As a closing point, we would like to emphasize that social responsibility will only be a success when it comes to all sectors. The economy and the public sector,

order in Romania, the problem, however, lies in enforcing this legislation. In 2011, the previously mentioned ISO 26000 standard was introduced in Romania as well, which has been developed to be applied not only by companies, but by all organizations - including public sector organizations. Both in 2011 and 2016 National CSR Strategies were adopted, and they have already contained some PSR elements. The aim of the first strategy was to raise awareness of the importance and benefits of CSR and to increase the involvement of the public sector, companies, multinational companies and civil society in the field of social responsibility. The strategy also mentions public sector organizations for most of the goals to be achieved, and assigns tasks and participation in social responsibility to them. The strategy, although it did not named or concretized it, actually conditioned public social responsibility for public sector organizations. Cornelia Pop: Corporate Social Responsibility in Romania: A Brief Survey (February 12, 2016). Studia. UBB Negotia, 2/2016, 83-104. Available at SSRN: https://ssrn.com/abstract=2898231 (12 April 2019) Corporate Social Responsibility in Romania - Netherlands Enterprise Agency https://english.rvo.nl/sites/default/ files/2017/03/Factsheet-Romania.pdf(12 April 2019) 
individuals and various civil society organizations must contribute to solving economic, social and environmental problems, because we can only cope with the massive, global problems that nowadays affect humanity together.

\section{REFERENCES}

A Social Value Act for Northern Ireland - Social Enterprise NI Position Paper, 2017. In. https://www.socialenterpriseni.org/sites/default/files/tenders/Social\%20 Value\%20Act\%20Position\%20Paper\%20310117.pdf

Corporate Responsibility Report - HM Government, 2008. In. https://www.educationandemployers.org/wp-content/uploads/2014/06/corporate-responsibility-report-hm-gov.pdf (

Global Catastrophic Risks 2018. Annual Report-Global Challenges Foundation In. https://api.globalchallenges.org/static/files/GCF-Annual-report-2018.pdf

Governmental Social Responsibility Model: An Innovative Approach of Quality in Governmental Operations and Outcomes https://www.mh.government.bg/media/ filer_public/2015/04/30/broshura.pdf

Greening Government Commitments Annual Report April 2016 to March 2017, February 2018. https://assets.publishing.service.gov.uk/government/uploads/system/ uploads/attachment_data/file/679636/ggc-annual-report-2016-17.pdf

Guidance: Social Value Act: Information and Resources, Cabinet Ofiice, 2016. May https://www.gov.uk/government/publications/social-value-act-information-and-resources/social-value-act-information-and-resources (14.10.2018)

HOWARD R. BOWEN: Social responsibilities of the businessman, Harper \& Row, New York,Report of the World Commission on Environment and Development: Our Common Future In. http://www.un-documents.net/our-common-future.pdf ISO 26000 - Social responsibility In: http://www.iso.org/iso/home/standards/iso26000. html

Kun Attila: Kötelezettség vagy önkéntesség? A társadalmi felelősség kérdése és a jogi megfelelés kultúrája. In: Jánosik, O. - Vörös, A. (szerk.): Társadalmi felelösségvállalás. Mit tehet a közszféra? HOPPÁ Disszeminációs füzetek, 2012, 36., http:// issuu.com/budapestimuvkp/docs/gsr_kiadvany_honlapra/13?e=1618624/ 14469561, (25.09.2018.)

Public Services (Social Value) Act, 2012. https://www.legislation.gov.uk/ukpga/2012/3/ contents/enacted

RANA KHAZBAK: Social Value in Procurement, NLGN, WSP Birmingham, 2016. In. https://www.base-uk.org/sites/default/files/news/Social-Value-in-Procurement_EVENT-WRITEUP.pdf (20.10.2018

S. LÓPEZ DAVIS, L. MARÍN RIVES, S. RUIZ DE MAYA: Introducing Personal Social Responsibility as a key element to upgrade CSR. In. Spanish Journal of Marketing - ESIC 2/2017

SARR-WILLIAM JABANG: An investigation into the use of public procurement and commissioning to deliver community (societal) value, 2016. $\mathrm{PhD}$ thesis 
Social Value Act Review, Cabinet Office, 2015. Február https:/assets.publishing. service.gov.uk/government/uploads/system/uploads/attachment_data/file/ 403748/Social_Value_Act_review_report_150212.pdf (20.10.2018)

Social Value in New Deveopment: An Introductory Guide for Local Authorities and Development Teams, UK Green Building Council, 2018. Március https://www. ukgbc.org/wp-content/uploads/2018/03/Social-Value.pdf (20.10.2018)

SzEGEDI Krisztina - MéLYPATAKI Gábor: A vállalati társadalmi felelősségvállalás (CSR) és a jog kapcsolata. Miskolci jogi Szemle, 2016/1. 51-70. Kun Attila: A multinacionális vállalatok szociális felelőssége, Ad Librum Kft., Budapest, 2009.

Társadalmi felelösségvállalás - Mit tehet a közszféra? HOPPÁ Disszeminációs Füzetek 36, Tempus Közalapítvány, 2012. (Social responsibility - What can the public sector do? HOPPÁ Dissemination Papers 36, Tempus Public Foundation, 2012.)

The Public Service (Social Value) Act 2012: An introductory guide for commissioners and policymakers; Department for Digital, Culture, Media \& Sport, 2018. In. https://assets.publishing.service.gov.uk/government/uploads/system/uploads/ attachment_data/file/690780/Commissioner_Guidance_V3.8.pdf

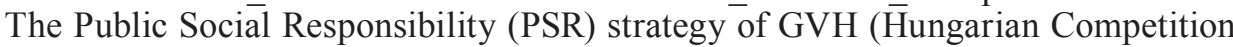
Authority) - http://www.gvh.hu/data/cms1036194/GVH_PSR_strategia_2017_ 04_27.pdf

THE SUSTAINABLE PROCUREMENT TASK FORCE - Procuring The Future In https://assets.publishing.service.gov.uk/government/uploads/system/uploads/ attachment_data/file/69417/pb11710-procuring-the-future-060607.pdf 
Dr Nora I. Jakab, vanredni profesor

Univerzitet $u$ Miškolcu

Pravni fakultet

civnora@uni-miskolc.hu

Žofija P. Raci, student radnog prava i socijalnog osiguranja

Univerzitet u Miškolcu

Pravni fakultet

zsofiaraczi@gmail.com

\section{Izazovi socijalne odgovornosti države u Velikoj Britaniji i Mađarskoj}

Sažetak: Koncept socijalne odgovornosti države pretrpeo je značajne promene u poslednjoj dekadi. Polazeći od pozitivnih strana koje ovaj koncept može da uvede u svakodnevni život pojedinca - od različitih aspekata privatnog do aspekata poslovnog života pojedinca - u članku su izložene pozitivne strane ovog koncepta i za samu državu. U tom kontekstu, polazeći od teškoća sa kojima se susreće savremena država u vezi sa reformom svoje administracije, autor upravo u konceptu socijalne odgovornosti vidi vodič po kojem treba da bude sprovedena pomenuta reforma. U članku su predstavljena rešenja koncepta socijalne odgovornosti Velike Britanije i Mađarske, sa posebnim osvrtom na specifičnosti anglosaksonskog modela socijalne odgovornosti države.

Ključne reči: socijalna odgovornost - pravo državne administracije inovacije u administraciji.

Datum prijema rada: 09.08.2019. 